\title{
First report of Neofusicoccum parvum causing canker and die-back of Eucalyptus in Spain
}

\author{
Eugenia Iturritxa • Bernard Slippers • Nebai Mesanza • \\ Michael J. Wingfield
}

Received: 11 January 2011 / Accepted: 15 June 2011 / Published online: 20 July 2011

(C) Australasian Plant Pathology Society Inc. 2011

\begin{abstract}
One of the most common groups of fungi causing canker on eucalypts is the Botryosphaeriaceae. A large number of species have been reported from this host in recent years. The Neofusicoccum parvum/ Neofusicoccum ribis species complex includes some of the most aggressive members of Botryosphaeriaceae. Cankers on stems are commonly sunken and elongated and infected tissue may be darkly pigmented. Bark cracking and kino exudation are often present. In this study Neofusicoccum parvum has been first reported as the main cause of canker disease in Eucalyptus globulus in North Spain.
\end{abstract}

Keywords Eucalyptus canker - Neofusicoccum parvum · Botryosphaeriaceae

A canker disease outbreak was observed for the first time on Eucalyptus globulus in North Spain, Vizcaya, during sampling in July 2009. Symptoms included dieback of shoots and branches, lesion and canker formation on the stems and brown and red exudates on stems and branches with copious exudation of kino. Eucalyptus globulus was established in the area in 1957 (Muro

E. Iturritxa $(\triangle) \cdot N$. Mesanza

Forest Health Neiker tecnalia,

Granja Modelo de Arkaute 46 Post,

Vitoria Gasteiz 01080 Álava, Spain

e-mail: eiturritxa@neiker.net

B. Slippers $\cdot$ M. J. Wingfield

Department of Genetics, Forestry and Agricultural Biotechnology

Institute (FABI), University of Pretoria,

Pretoria 0002, South Africa
1975). The expansion of fast growing eucalypt plantations was stimulated by the increase of demands from the rapidly growing pulp industry. As in other parts of the world, pest and pathogens are rapidly emerging as one of the greatest threats to such plantation forestry based on non-native species (Wingfield 2003; Old et al. 2003; Old and Davison 2000). The most well-known disease of eucalypts in Spain is leaf spot caused by Mycosphaerella species. Various species of Mycosphaerella have been found on Eucalyptus in plantations (Crous et al. 2006; Otero et al. 2004; De Blas et al. 2009). There is, however, little known about other diseases on this host and clearly a significant need exist to expand the knowledge on eucalyptus health in Spain. Diseased samples of E. globulus were cultivated on oatmeal agar $(\mathrm{OA})$ and incubated at $25^{\circ} \mathrm{C}$. Fungal isolates developed abundant, aerial mycelium that became dark grey after 2-3 days and formed black, globular pycnidia after 2 weeks. Conidia were hyaline, aseptate, not becoming septate or darker with age, thin walled and fusiform and measured 18.9-23 $\times 4-4.9 \mu \mathrm{m}$. Furthermore, the ITS rDNA locus was amplified and sequenced using the ITS1 and ITS4 primers, and compared to sequences in GenBank using BLAST. Based on the symptoms, cultural morphology, conidial characters and sequencing (GenBank Accession numbers JN119283 and JN119284; 100\% identity to the ex-type isolate CMW9081) the fungus was identified as Neofusicoccum parvum (Pennycook \& Samuels) Crous, Slippers \& A.J.L. Phillips. The isolates used in this study are maintained in the culture collection of the Forestry and Agricultural Biotechnology Institute (FABI), University of Pretoria, South Africa and in Agricultural Institute of Neiker, in the Basque Country, Spain, culture collection numbers CMW37773 and CMW36774.

To confirm pathogenicity, an inoculation experiment was conducted. Two $\mathrm{mm}$ diameter actively growing mycelium plugs of $N$. parvum were applied to the same size bark 
wounds on the middle point of the stems of seedlings of E. globulus. Control plants were inoculated with sterile PDA plugs. The inoculation was carried out under controlled conditions in the greenhouse (temperature $22 \pm$ $3^{\circ} \mathrm{C}$, relative humidity $65 \pm 5 \%$ ). After 3 weeks, all the inoculated seedlings showed dark vascular stem tissue, with a size lesion $4,3 \pm 1,9 \mathrm{~cm}$. $N$. parvum was reisolated from all the inoculated tissues. No symptoms were visible in the control seedlings and no fungus was isolated from them.

Neofusicoccum parvum has previously been reported as causing canker symptoms of Eucalyptus species in many parts of the world, including Australia, Chile, China,
Ethiopia, Indonesia, South Africa, Uganda, Uruguay, Venezuela (Rodas et al. 2009). Previous Botryosphaeria dothidea (Moug. Ex Fr.) Ces. \& De Not. and Neofusicoccum ribis Grossenb \& Dugg. was thought to be common on Eucalyptys, but DNA sequence comparisons have now shown that many of the early identification were possibly incorrect and that these species are rare on Eucalyptus. Earlier reports of these fungi probably represent species such as $N$. parvum and others (Slippers et al. 2004a, b; Burgess et al. 2005; Rodas et al. 2009).

To the best of our knowledge, this is the first report of $N$. parvum causing eucalypt canker in Spain.
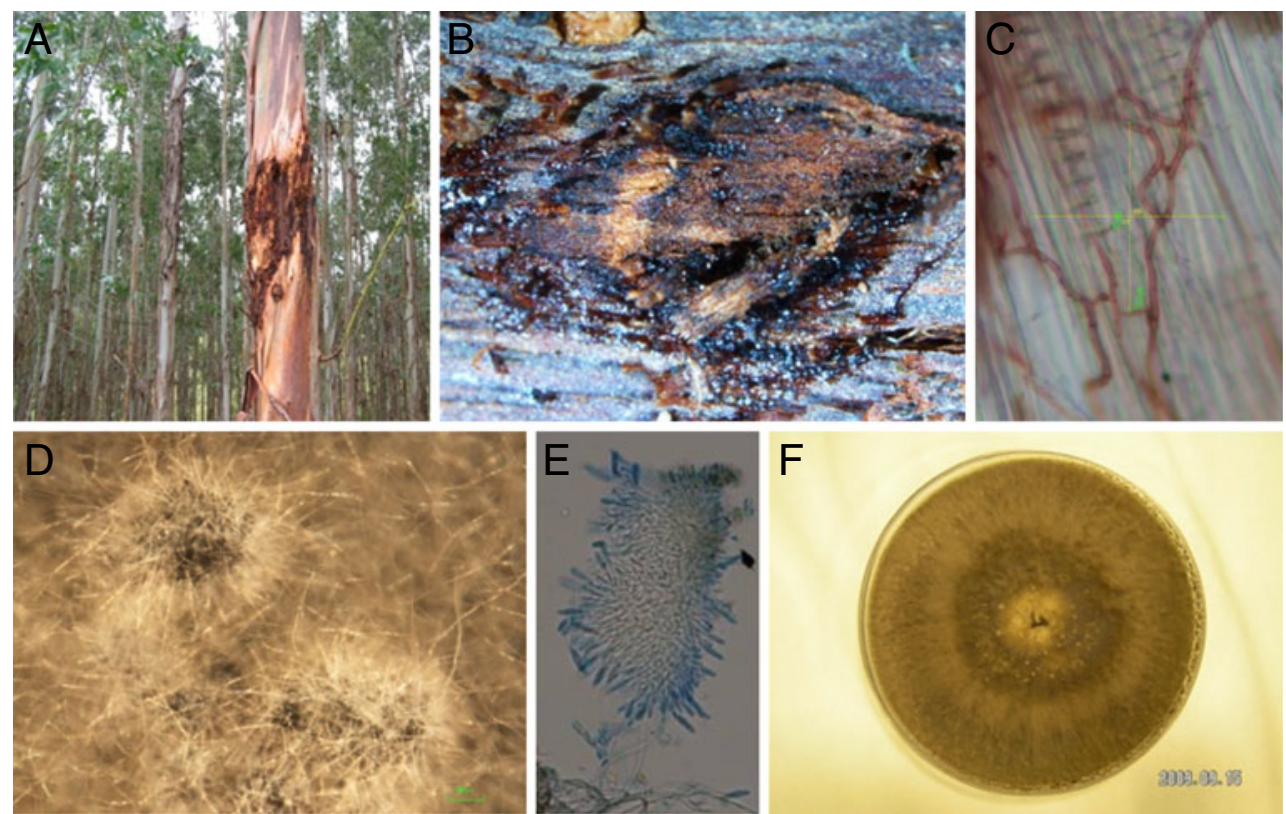

A: Eucalyptus globulus plantation, showing advanced stem canker. B: Exudation of kino on stem with severe canker. C: Micellial invasion of Eucalyptus tissues. D: Fruiting bodies of Neofusiccocum parvum growing on oatmeal agar. E: Conidia and conidiophores. F: Appearance of culture on oatmeal agar

\section{References}

Burgess TI, Barber PA, Hardy GEStJ (2005) Bothryosphaeria spp. associated with Eucalyptus in Western Australia including description of Fusicoccum macroclavatum sp. Nov. Australas Plant Pathol 34:557-567

Crous P, Groenewald J, Mansilla JP, Montenegro D, Pintos C (2006) Identification de species de Mycosphaerella en Eucalyptus globules y E. nitens en Galicia. Proceedings of the thirteenth National Symposium of the Spanish Society of Plant Pathology, 2006. Murcia Spain 2007

De Blas B, Iturritxa E, Diez J (2009) New species of Mycosphaerella causing leaf spot on Eucalyptus globulus in Spain. Australas Plant Dis Notes 2009(4):59
Muro R (1975) El acervo forestal, Bilbao: Caja de Ahorros Vizcaina. Colección temas vizcainos, 8: $55 \mathrm{pp}$

Old KM, Davison EM (2000) Canker diseases of Eucalyptus. Diseases and Pathogens of Eucalyptus. In: Keane PJ, Kile GA, Podger FD, Brown BN (eds), CSIRO 2000, 241-257

Old KM, Wingfield MJ, Yuan ZQ (2003) A manual of diseases of eucalypts in South-east Asia. Centre for International Forestry Research, Indonesia

Otero L, Augín O, Mansilla JP, Hunter GC, Wingfield MJ (2004) Identificación de species de Mycosphaerella en Eucalyptus globulus y E. nitens en Galicia. Proceeding of the Thirteenth National Symposium of the Spanish Society of Plant Pathology. 2006. Murcia, Spain: 207

Rodas CA, Slippers B, Gryzenhout M, Wingfield MJ (2009) Botryosphaeriaceae associated with Eucalyptus canker diseases in Colombia. For Path 39(2009):110-123 
Slippers B, Crous PW, Denman S, Couthino TA, Wingfield BD, Wingfield MJ (2004a) Multiple gene genealogies differentiate several species in the Botryosphaeria dothidea species complex. Mycologia 96:83-101

Slippers B, Fourier G, Crous PW, Couthino TA, Wingfield BD, Carnegie A, Wingfield MJ (2004b) Speciation and distribution of Bothryosphaeriaceae on native and introduced Eucalyptus trees

Wingfield MJ (2003) Increasing threat of diseases to exotic plantation forest in the Southern Hemisphere: lessons from Cryphonectria canker. Australas Plant Pathol 32:133-139 